\title{
Between Reality and the Needs: Responsibilities of Educational Institutions in Developing Archival Science in Indonesia
}

Paper Type:

Research Paper

Submitted 24 April 2019 Accepted 22 December 2019

\section{${ }^{1}$ Program Studi Kearsipan Sekolah Vokasi UGM \\ ${ }^{2}$ Direktorat Jenderal Kekayaan Negara Kementerian Keuangan RI}

\section{Abstract}

Background of the study: The requirement of Archivists (archivist and records manager) in Indonesia is not equal to the quantity of graduates produced by educational institutions. In addition 4.0 with the educational requirements and the needs of stakeholders who want graduates from the archival field at the highest level should be accommodated. Therefore, educational institutions are forefront in developing archival science.

Purpose: This study aims to find out how the responsibility of educational institutions in developing the knowledge of the field of archives in Indonesia in the era of information technology

Method: This study uses descriptive qualitative, interviews, and literature studies.

Findings: This study discusses the Efforts of educational institutions to improve the archival science by establishing a higher education program through the mindset of building and synergy with other elements. In addition, educational institution has responsibility in the archival field in Realizing the archival sense. Conclusion: Archival science more interpreted in a theoretical structure that supports the activities of archival practical, rather than academic disciplines. If the method is applied science, the science of archives will tend to be highly empirical making it a descriptive science. This tendency will make archival science seeks only to gather facts and less attention to the development of the concept as well as demanded by the development of science through a study. To develop scientific archives in Indonesia, the necessary synergy between archival institutions, archival professional associations, educational institutions allied, as well as among students in educational institutions. This must be done with the agreement in the field of archives that apply universally to realize the creation of the organization of archives in Indonesia better.

Keywords: educational institution, responsibility, mindset, synergy, archival science 


\section{Introduction}

Scientific developments in the field of archives in Indonesia related to educational institutions that provide education archives at diplomas level three and four diploma is still relatively rare. Organizes study programs is still limited specialization archives, among others; Gadjah Mada University, Diponegoro University, Brawijaya University, Hasanuddin University, the University of Indonesia and the Open University (D-IV). On the other hand, the education provider in the field of archives developed countries has entered the master's or doctoral level program (graduate program). The position of the field of archives in Indonesia classified as science is still not fully accepted in the academic world. This relates to the number of faculty, human resources, and academic networks. Research activities are also becoming an important element in order that the field of archives can be fully accepted as a science. According Scheurkogel, archivists looked likely not be the researcher and are usually referred to as a professional "traditional". In European countries shows that the change in the modern development of professional view on the theory of archival education with an academic approach could be recommendations for institutions to stimulate activity in the study. Product resources that will be generated is as a modern professional (Scheurkogel, 2006). Indonesia archivists professional development in the field of research becomes absolutely necessary, though not the main task as stipulated in the Regulation of the Minister of Administrative Reform No. 48 Year 2014 (Widodo, 2017). Archivist looked likely not be the researcher and are usually referred to as a professional "traditional". In European countries shows that the change in the modern development of professional view on the theory of archival education with an academic approach could be recommendations for institutions to stimulate activity in the study. Product resources that will be generated is as a modern professional (Scheurkogel, 2006). Indonesia archivists professional development in the field of research becomes absolutely, necessary though not the main task as stipulated in the Regulation of the Minister of Administrative Reform No. 48 Year 2014 (Widodo, 2017). Archivist looked likely not be the researcher and are usually referred to as a professional "traditional". In European countries shows that the change in the modern development of professional view on the theory of archival education with an academic approach could be recommendations for institutions to stimulate activity in the study. Product resources that will be generated is as a modern professional (Scheurkogel, 2006). Indonesia archivists professional development in the field of research becomes absolutely necessary, though not the main task as stipulated in the Regulation of the Minister of Administrative Reform No. 48 Year 2014 (Widodo, 2017). In European countries shows that the change in the modern development of professional view on the theory of archival education with an academic approach could be recommendations for institutions to stimulate activity in the study. Product resources that will be generated is as a modern professional (Scheurkogel, 2006). Indonesia archivists professional development in the field of research becomes absolutely necessary, though not the main task as stipulated in the Regulation of the Minister of Administrative Reform No. 48 Year 2014 (Widodo, 2017). In European countries shows that the change in the modern development of professional view on the theory of archival education with an academic approach could be recommendations for institutions to stimulate activity in the study. Prod uct resources that will be generated is as a modern professional (Scheurkogel, 2006). Indonesia archivists professional development in the field of research becomes absolutely necessary, though not the main task as stipulated in the Regulation of the Minister of Administrative Reform No. 48 Year 2014 (Widodo, 2017). Indonesia archivists professional development in the field of research becomes absolutely necessary, though not the main task as stipulated in the Regulation of the Minister of Administrative Reform No. 48 Year 2014 (Widodo, 2017). Indonesia archivists professional development in the field of research becomes absolutely necessary. though not the main task as stipulated in the Regulation of the Minister of Administrative Reform No. 48 Year 2014 (Widodo, 2017).

During its development, educational institutions in the field of archives Indonesia are faced with the reality of the number of graduates who are not comparable with the needs. Educational institutions are responsible for the creation of quality graduates. Therefore, the spirit of the scientific

To cite this document:

Bramantya, A.R., Prasetyo, A. (2019). Between Reality and the Needs: Responsibilities of Educational

Institutions in Developing Archival Science in Indonesia. Record and Library Journal. 5 (2), 136 - 149.

Open access under Creative Commons Attribution-Non Commercial-Share A like 4.0 International Licence 
field of archives in terms of mastery of concepts becomes absolutely necessary. Archival science by Duranti is the body of knowledge about the nature and characteristics of archives and archival work systematically organized into theory, methodology, and practice, The emphasis on theory and methodology underlying the ability of practice, the application of science in the archival method is required as a science. In addition, the principles and concepts as well as archival context were applied in archival research. The quality of research results must meet the standards and the validity of which meet the elements of consistency in meaning and logic, free from political influence and cultural (Duranti, 1989). Archival educational model according to Duranti divided into four, namely referring to the historical background (historical model), philological (philological model), managerial (managerial model) and scientific (scholarly or scientific model). Historical models focused on the needs of historical knowledge in the education of archives because the essence of the activities is to translate the archive in terms of functionality, competence, and archivist activities (archivist). Philological the model focuses on the meaning and structure in the ancient documents with a focus on archive material. The managerial model of focusing on users in a community context that emphasizes the content, information related to access, privacy, freedom of information, retrieval, and so forth. Scholarly or scientific models focused on understanding the theory, methodology, and practice is a combination of pure and applied science, archival and widely adopted by universities that provide educational archives. The fourth model of the knowledge related to the concepts of archives and archival functions and methods, but each model has a different context of the framework.

The development of archival science is interpreted directly proportional to the archival profession and vice versa archival profession should be analyzed with developments in society. The development serves as the demands on education and research archives. Archival science as an academic discipline is a subject that emphasizes the needs of the community. Coupled with technological advances in the field of Artificial Intelligence, Internet of Things (IOT), and various other technological advances make archival science should be able to adjust the scientific development. The development of information and communication technologies have a major impact on the perception of the archive. President Joko Widodo even mentioned the quality of education has been improved up to now is the vocational education programs for professional certification. The program is expected to create the productive age in Indonesia can live to work. Component Builder Indonesian human resources that are in the realm of education will play an active role in the intellectual life of the Indonesian people in a professional manner to achieve the national goal of Indonesia as mandated in the 1945 Constitution of Indonesia's human resources associated with the need for archivists at all levels should be taken into account. Management of cloud-based archive to hold on knowledge of technology should be of particular concern, given the archivist does not only manage the conventional archives, but will be dealing with digital archives (Asmiyanto, 2018). On the other hand, the condition of archival management in Indonesia are still struggling in the conventional archives.

In industrial societies, archivists are professionals with knowledge of monopolists. In the information society, the professionals are poorly appreciated because of the knowledge and competencies they have. The development of technology along with the development of knowledge lead to knowledge would quickly become obsolete. Therefore, the activities of an archivist, professionalism should be appreciated by the public, who had been a professional domain industry professionals to switch to the information age. Professional work is no longer equated with work in the public sector alone, but includes the private sector. Working world will be looking for people with the technology literacy skills, analytical abilities and decision-making, interpersonal skills, and the ability to work independently and in teams (Scheukogel, 2006). Archivists must have media literacy competence given the responsibility and the strategic role given to the organization that later on they will be able to search, understand, analyze and communicate information (Santoso, 2016).

National Archives of the Republic of Indonesia, adding that the national archiving needs by calculating the formation archivists are as many as 142760 people, while the number of which there

To cite this document:

Bramantya, A.R., Prasetyo, A. (2019). Between Reality and the Needs: Responsibilities of Educational

Institutions in Developing Archival Science in Indonesia. Record and Library Journal. 5 (2), 136 - 149.

Open access under Creative Commons Attribution-Non Commercial-Share A like 4.0 International Licence 
were 3855 people in the year 2018. The calculation of formation archivists available includes the Ministry or the State Agency of Indonesia, the Provincial Government and the City and District Education State. Archivists needs analysis can actually be seen from the number of archival institutions in Indonesia, ministries, state enterprises, and the private sector.

\section{Kebutuhan Arsiparis}

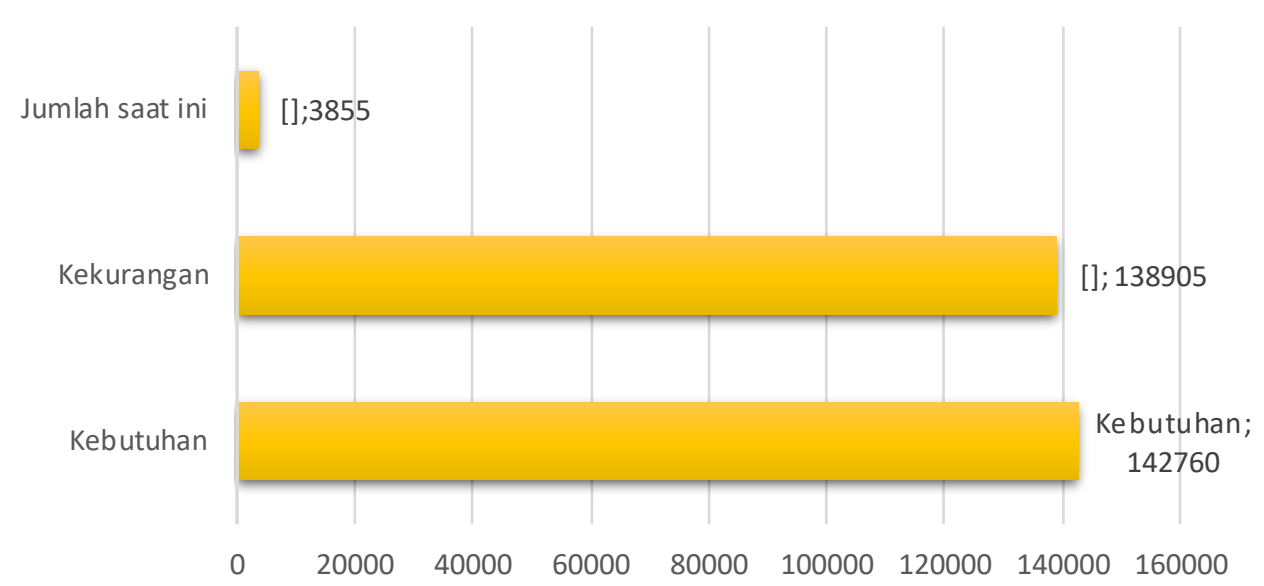

Graph 1. Needs archivist Ind onesia (source: National Archives of the Republic of Indonesia, 2018)

From the background mentioned above can be formulated fundamental question, namely how the responsibility of educational institutions in developing the knowledge of the field of archives in Indonesia in the era of information technology? On the other hand, education providers are still rare archival field. Archive management as well as managing science. The scientific field of archives cannot be seen and is positioned as a subordinate if aligned with science or library and information science.

\section{Method}

The research method is absolutely necessary to build an explanation for the problem. This research was conducted using the method of literature study and interviews in order to obtain primary and secondary data that will clarify the analysis and qualitative methods to collect as much material as possible from the source-cracked clear information to get a general idea in detail. Qualitative research explores the quality of the data, thus freeing researchers from the quantity of figures and sources. Data collection techniques can be done with interviews, observations or surveys. Stages in qualitative research refer to the planning, observation, data collection, and writing. (Moleong, 2013). First, it is necessary to search the literature in the form of books and journals related to the research theme. Other than that, interviews were conducted to the Head of UGM Archive 2008-2014 period and administrators Archival Indonesian Student Association. Topics in an interview, referring to the fundamental needs in the field of Archives of scientific development. This research is juridical empirical because this research focuses on thorough research, systematic and accurate, and supported by research literature and secondary data that has been available previously. The results of this research are descriptive analytic investigated by describing the state of the subject or object in the study is based on facts. Data were analyzed using triangulation techniques. According to Denzin,

\section{Result and Discussion Systematic Thinking}

"The confusion occurred because the discourse of the archive is still a mix between those oriented to the Netherlands with their concept oriented AngloSaxon concept. Meanwhile, Indonesia, which has entered the era of

To cite this document:

Bramantya, A.R., Prasetyo, A. (2019). Between Reality and the Needs: Responsibilities of Educational Institutions in Developing Archival Science in Indonesia. Record and Library Journal. 5 (2), 136 - 149. 
globalization and the market together, in a predominantly English have a different understanding with the Dutch on records"(Sulistyo, 2009).

The above quotation is indirectly implying that the term archives, especially in the education field of archives there are ambiguities and inconsistencies. Formal education is the spirit connector in the development and establishment of the mindset of the field of archives.It was generally agreed that education has a function to form a professional mindset and look at the whole idea of learning which are the roots of the profession. On the other hand, training is a mold according to the pattern that can be replicated in skills development, the acquisition of practical knowledge and specialization in the field of development which have been determined. Therefore, education makes learning to think as an archivist and allow them to act professionally with the intellectual capacity associated with specific experience gained (Duranti, 2007). Currently, in some parts of the world not yet fully emerged that public perception of the archivist and records manager (archivist). Most of them complained that their profession is not seen by the public (Cox; Larsen, 2008).

The simplest smallest part in instilling a full understanding related to the field of archives beginning of understanding the terminology and concepts used. Understanding the terminology of the field of archives in accordance with the social agreement archival profession related to the field of archives of scientific development becomes important. On the other hand, the meaning of archive freely theorists humanities should also be understood and complementary. Pros and cons of the concept of social consensus and archives through humanities theorist if associated with educational institutions in particular that conduct educational programs in the field of archives academic realm would be a very interesting discourse. Suprayitno, suggests some understanding of the archive via a semiotic perspective philosopher like Michel Foucault and Derrida. The views Foucoult, through a semiotic perspective, the archive can be interpreted as a discourse and power. While Derrida's view, the archive as a law (Suprayitno, 2017).

As an educational institution which holds the cutting edge of scientific development, consistent understanding of the term field of archives is the main basis in the learning process. The responsibility of educational institutions to adjust the mention of the term field of archives become obligatory. The mention of the term "archive" by the people it is still an issue. The term "archive" is used in everyday situations is the uptake of the Dutch language. Meanwhile, in the vocabulary of the Dutch language is also known as the term dynamisch Archief (records) and statisch Archief (archives). Djoko Utomo confirms that the archive is the Indonesian term for Record and Archives (Utomo, 2017). The problem is the use of the term "archive" in Indonesia, generally become unclear whether it refers to the dynamic or static archive. Terms such as "Records Retention Schedule", "Vital Records", in a scientific standpoint and according to archival science literature that are in the realm of Records Management that is "vital records" and "Records Retention Schedule". If consistent with the uptake of the Dutch language course referring to the archives. Little things like this that should be straightened out in the learning process as an effort for the development of the scientific field of archives. Not infrequently, inconsistencies in the names of subjects in the curriculum of the education agency that organizes archival often encountered. Confusion understanding of archives and archival must be parsed immediate urgency, starting with in-depth studies on aspects of the philosophy of science, history of development, meaning and application in Indonesia (Waluyo, 2018) in a scientific standpoint and according to archival science literature that are in the realm of Records Management that is "vital records" and "Records Retention Schedule". If consistent with the uptake of the Dutch language course referring to the archives. Little things like this that should be straightened out in the learning process as an effort for the development of the scientific field of archives. Not infrequently, inconsistencies in the names of subjects in the curriculum of the education agency that organizes archival often encountered. Confusion understanding of archives and archival must be parsed immediate urgency, starting with in-depth studies on aspects of the philosophy of science, history of development, meaning and application in Indonesia (Waluyo, 2018) in a scientific standpoint and according to archival science literature that are in the realm of Records Management that is "vital

To cite this document:

Bramantya, A.R., Prasetyo, A. (2019). Between Reality and the Needs: Responsibilities of Educational

Institutions in Developing Archival Science in Indonesia. Record and Library Journal. 5 (2), 136 - 149.

Open access under Creative Commons Attribution-Non Commercial-Share A like 4.0 International Licence 
records" and "Records Retention Schedule". If consistent with the uptake of the Dutch language course referring to the archives. Little things like this that should be straightened out in the learning process as an effort for the development of the scientific field of archives. Not infrequently, inconsistencies in the names of subjects in the curriculum of the education agency that organizes archival often encountered. Confusion understanding of archives and archival must be parsed immediate urgency, starting with in-depth studies on aspects of the philosophy of science, history of development, meaning and application in Indonesia (Waluyo, 2018) If consistent with the uptake of the Dutch language course referring to the archives. Little things like this that should be straightened out in the learning process as an effort for the development of the scientific field of archives. Not infrequently, inconsistencies in the names of subjects in the curriculum of the education agency that organizes archival often encountered. Confusion understanding of archives and archival must be parsed immediate urgency, starting with in-depth studies on aspects of the philosophy of science, history of development, meaning and application in Indonesia (Waluyo, 2018) If consistent with the uptake of the Dutch language course referring to the archives. Little things like this that should be straightened out in the learning process as an effort for the development of the scientific field of archives. Not infrequently, inconsistencies in the names of subjects in the curriculum of the education agency that organizes archival often encountered. Confusion understanding of archives and archival must be parsed immediate urgency, starting with in-depth studies on aspects of the philosophy of science, history of development, meaning and application in Indonesia (Waluyo, 2018) inconsistency of subjects in the name of the educational institution that organizes archival curriculum often encountered. Confusion understanding of archives and archival must be parsed immediate urgency, starting with in-depth studies on aspects of the philosophy of science, history of development, meaning and application in Indonesia (Waluyo, 2018) inconsistency of subjects in the name of the educational institution that organizes archival curriculum often encountered. Confusion understanding of archives and archival must be parsed immediate urgency, starting with in-depth studies on aspects of the philosophy of science, history of development, meaning and application in Indonesia (Waluyo, 2018). 


\begin{tabular}{|c|c|c|c|}
\hline $\begin{array}{l}\text { D III Archival Studies } \\
\text { Program Gadjah Mada } \\
\text { University Vocational } \\
\text { School }\end{array}$ & $\begin{array}{l}\text { D III Study Program } \\
\text { Informational and } \\
\text { document } \\
\text { management, } \\
\text { Universityof } \\
\text { Indonesia }\end{array}$ & $\begin{array}{l}\text { D IV Studies } \\
\text { Program } \\
\text { Archives and } \\
\text { Records } \\
\text { management } \\
\text { information Open } \\
\text { University }\end{array}$ & $\begin{array}{l}\text { Study Program D III } \\
\text { Diponegoro } \\
\text { University Archives }\end{array}$ \\
\hline $\begin{array}{ll}- & \text { Management } \\
& \text { record center }\end{array}$ & $\begin{array}{ll}- & \text { Management } \\
& \text { Archives } \\
- & \text { Archive } \\
& \text { Management } \\
- & \text { Practicum } \\
& \text { inactive }\end{array}$ & $\begin{array}{l}\text { - Planning } \\
\text { Records } \\
\text { Retention } \\
\text { Schedule } \\
\text { - Management } \\
\text { Archives } \\
\text { - Management } \\
\text { archive inactive }\end{array}$ & 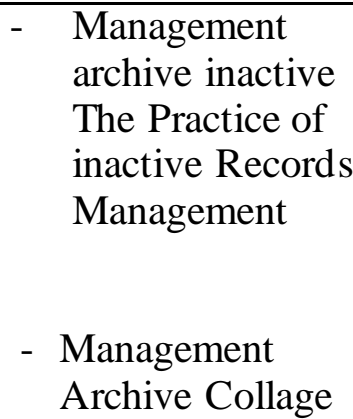 \\
\hline $\begin{array}{l}\text { Management } \\
\text { filling business } \\
\text { and Higher } \\
\text { Educational } \\
\text { Institutions }\end{array}$ & & $\begin{array}{l}\text { Business - } \\
\text { Archive }\end{array}$ & \\
\hline $\begin{array}{l}\text { - Management } \\
\text { Archives Audio } \\
\text { Visual }\end{array}$ & & 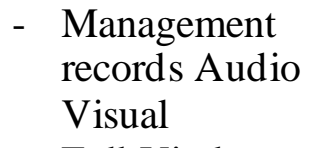 & $\begin{array}{l}\text { - Management } \\
\text { Vital Archives } \\
\text { and Special }\end{array}$ \\
\hline \multirow[t]{2}{*}{$\begin{array}{l}\text { - Program Vital } \\
\text { and Records } \\
\text { and Archives } \\
\text { Management } \\
\text { After Nature } \\
\text { Disasters }\end{array}$} & $\begin{array}{ll}\text { - } & \text { Practicum } \\
\text { Records } \\
\text { Management }\end{array}$ & $\begin{array}{l}\text { - Full Vital } \\
\text { Record }\end{array}$ & Shape \\
\hline & $\begin{array}{l}\text { - Archive Archives } \\
\text { Management- } \\
\text { Practicum }\end{array}$ & $\begin{array}{l}\text { Management } \\
\text { Active Record }\end{array}$ & $\begin{array}{l}\text { Management } \\
\text { Active Archive } \\
\text { The Practice of } \\
\text { Active Records } \\
\text { Management }\end{array}$ \\
\hline $\begin{array}{l}\text { - Management } \\
\text { Electronic } \\
\text { Archive }\end{array}$ & $\begin{array}{ll}\text { - } & \text { Electronic } \\
\text { Archive - } \\
\text { Introduction } \\
\\
\text { - } & \text { Electronic } \\
\text { Records } \\
\text { Management - } \\
\text { Practicum }\end{array}$ & $\begin{array}{ll}\text { - } & \text { Full } \\
\text { Electronic } \\
\text { Erchive }\end{array}$ & $\begin{array}{l}\text { - Management } \\
\text { Electronics and } \\
\text { Automation } \\
\text { Archive Filling }\end{array}$ \\
\hline
\end{tabular}

Source: Adapted from various sources of data curriculum.

To cite this document:

Bramantya, A.R., Prasetyo, A. (2019). Between Reality and the Needs: Responsibilities of Educational Institutions in Developing Archival Science in Indonesia. Record and Library Journal. 5 (2), 136 - 149. 
The scientific field of archives can be said to be dynamic and growing. Advances in technology also developed rapidly. Therefore, the purpose of education is to prepare resources for the future rather than indoctrinating them with the practices and contradictory thoughts at the moment. Understanding of the theoretical and practical issues related to the electronic archive is one part of a broader range of work documentation. In the face of the Industrial Revolution 4.0, strengthening the scientific field of archives through the courses in the curriculum should be consistent with the understanding of the terminology. Archivists have challenges in the management of archives (archives and records) in the future, which will lead to the base of digital technology and cloud computing. The phenomenon of the Internet of Things can not be underestimated. The public will be faced with big data, artificial intelligence, and financial technology. Challenges teacher entered the era of industrial revolution in 4.0, especially the field of archives should be able to adjust and learn the changes with the massive development of technology. Therefore, teachers should be able to understand its development and be able to digital literacy. In addition, the teacher was required to adjust the learning by utilizing information technology infrastructure and curriculum redesign. Citing M. Nasir (2018) in the National Workshop to held at the University of North Sumatra that Therefore, teachers should be able to understand its development and be able to digital literacy. In addition, the teacher was required to adjust the learning by utilizing information technology infrastructure and curriculum redesign. Citing M. Nasir (2018) in the National Workshop to held at the University of North Sumatra that Therefore, teachers should be able to understand its development and be able to digital literacy. In addition, the teacher was required to adjust the learning by utilizing information technology infrastructure and curriculum redesign. Citing M. Nasir (2018) in the National Workshop to held at the University of North Sumatra that

"The strategic policy needs to be formulated in various aspects ranging from institutional, field of study, curriculum, resources, and the development of cyber university, risbang to innovation. I hope in this congress can be generated on Higher Education of science and technology development in the face of the industrial revolution $4.0^{\prime \prime}$

With so many changes and a new perspective on the field of archives that appeared in the last few years, it's time to reconsider the purpose and perspective and an educational component archive in Indonesia. Complexity, institutional and selection of information technologies require more innovative learning in the educational program archives. The basic components such as the theory, methodology, and practice remains fundamental. In addition, learners need the skills and foundation in technology and good interpersonal skills and cultural understanding to lead your organization or institution in the future. Randall (2010) suggested several recommendations related to the field of archives for the future, among others; a) archival education should be emphasized why; what and how the scientific field of archives to be important, in harmony with the basic purpose why the archives there and why archivists perform its functions, b) direct experience is required through practical activities, c) students must pass to find out why and how to work as a profession, d) the archivist should always remember that technology is a means, not an end, e) understand and use technology is very important, but it should not be the main objective of professional education, $\mathrm{f}$ ) education should be more emphasis on ethics and moral values archival profession, $\mathrm{g}$ ) the learner must understand the role of archives and archivists in society, including element- inherent element with power in society, including historical understanding, memory, accountability and defense, democracy and diversity, and social justice. (Randall, 2010) b) direct experience is required through practical activities, c) students must pass to find out why and how to work as a profession, d) the archivist should always remember that technology is a means, not an end, e) understand and use of technology is very important, but it should not be the main purpose of professional education, $f$ ) education should be more emphasis on ethical and moral values of the profession of archival, g) the learner must understand the role of archives and archivists in society, including elements attached to the power in society, including historical understanding, memory, accountability and defense,

To cite this document:

Bramantya, A.R., Prasetyo, A. (2019). Between Reality and the Needs: Responsibilities of Educational

Institutions in Developing Archival Science in Indonesia. Record and Library Journal. 5 (2), 136 - 149.

Open access under Creative Commons Attribution-Non Commercial-Share A like 4.0 International Licence 
democracy and diversity, and social justice. (Randall, 2010) b) direct experience is required through practical activities, c) students must pass to find out why and how to work as a profession, d) the archivist should always remember that technology is a means, not an end, e) understand and use of technology is very important, but it should not be the main purpose of professional education, $\mathrm{f}$ ) education should be more emphasis on ethical and moral values of the profession of archival, g) the learner must understand the role of archives and archivists in society, including elements attached to the power in society, including historical understanding, memory, accountability and defense, democracy and diversity, and social justice. (Randall, 2010) d) the archivist should always remember that technology is a means, not an end, e) understand and use of technology is very important, but it should not be the main objective of professional education, $\mathrm{f}$ ) education should be more emphasis on ethical and moral values of the profession of archival, g) learners must understand the role of archives and archivists in society, including elements attached to the power in society, including historical understanding, memory, accountability and defense, democracy and diversity, and social justice. (Randall, 2010) d) the archivist should always remember that technology is a means, not an end, e) understand and use of technology is very important, but it should not be the main objective of professional education, $f$ ) education should be more emphasis on ethical and moral values of the profession of archival, g) learners must understand the role of archives and archivists in society, including elements attached to the power in society, including historical understanding, memory, accountability and defense, democracy and diversity, and social justice. (Randall, 2010) g) the learner must understand the role of archives and archivists in society, including elements attached to the power in society, including historical understanding, memory, accountability and defense, democracy and diversity, and social justice. (Randall, 2010) g) the learner must understand the role of archives and archivists in society, including elements attached to the power in society, including historical understanding, memory, accountability and defense, democracy and diversity, and social justice. (Randall, 2010)

In the industrial society, people who are competent in a specific field with a diverse level is the result of the learning process through the curriculum. What is required at the time of the transition of industrial society into the information age society?. In the information society, learners acquire learning instrument to discover and develop the knowledge initially educators simply transferring knowledge. In the information society, learning methodology focuses on understanding general and specific problem solving as well as on information processing (Thomassen, 2001). Ideally, the educational profile intersects with the professionalism that will produce human resources ready to work professionally. Other than that,

\section{Synergy in the field of Archives of scientific development.}

This challenge has been predicted to emerge as information and communication technology (ICT) will continue to grow, which will have a direct impact on the practice of filing, either in the physical form of the archive will be created, the model list archives, methods of recovery of archives (retrieval), and methods preservation in the form of non-textual. To address this challenge the professionals in the field of archives, especially in Indonesia, should have the competence that is able to adapt to the development of archives. One important competence in the development of technology that is associated with archival curation. Curation serves as a useful mechanism to represent the preservation of as an expanded function of traditional documentation and artifactual sources. Other than that, synergy and collaboration is the key factor in the development of science. The synergy and collaboration means is not limited to museums, libraries, archives but entering a new community, such as science, engineering, and commercial sectors (Zorich, 2007).

Law No. 43 Year 2009 concerning the Filing chapter 1 verse 10 states that archivists are someone who has competence in the field of archives acquired through formal education and training or education as well as archival and have the functions, duties, and responsibilities of conducting archival. One example is the formal education through educational institutions in this regard is

To cite this document:

Bramantya, A.R., Prasetyo, A. (2019). Between Reality and the Needs: Responsibilities of Educational

Institutions in Developing Archival Science in Indonesia. Record and Library Journal. 5 (2), 136 - 149.

Open access under Creative Commons Attribution-Non Commercial-Share A like 4.0 International Licence

(CC-BY-SA) (c) (i) (2) 
college. Therefore, educational institutions have an obligation to conduct archival education in accordance with the challenges and changing times, so as to create a good archivist with competence in the field. But do not deny also that the realization of a good archival ed ucation provision, first have to go through a synergy between related elements as the organizer of archives. With this synergy, it will produce an archival standard of education curriculum in accordance with the development of archives and is able to meet market demand.

Understanding the archives through the development of technology, requires an understanding of the cultural, economic, political, historical, and others affecting the nature of the information. The lack of understanding of the characteristics of archives may be caused by limited resources and lack of archival education providers. Very difficult to establish a comprehensive program of archival educational when only one or two faculty who have a greater responsibility than simply teaching or when the program archival and preservation activities are very rarely or limited in the scope of their own activity (Cox, Larsen, 2008).

Tracing the development of the archival profession in Australia is done through synergy between the elements of archives in the country, ranging from archival institutions, professional associations, educational institutions and others (Effendhie, 2017). In Indonesia, the elements relating to the organization of archival require a synergy together, such as archival institutions (national, provincial, district or city, and universities), Professional Association (Association of Archivists Indonesia), Institution organizer Education field of archives (although the numbers are still very minimal), P3RI (Association of Indonesian Record Profession business) and so forth. However, to what extent have synergy between these elements run in Indonesia? The synergy is certainly absolutely necessary, one of them to create a better teaching standards for educational institutions. Because educational institutions as one of the elements that will create the archivists in Indonesia. Ideally, in the context of the development of archival Indonesia, there needs to be an independent association or associations, so as to have a high bargaining power in the process of development of archives.

In step archival scientific development, in addition to the synergy with archival institutions and professional associations, educational institutions synergy between archival also indispensable. This is done as a step to create a learning process related consistenly given curriculum, so the archivists printed by each educational institution have the capability to match, at least equivalent to the understanding of theory and practice. In addition, various forms of study and research should be strengthened. As it is known that that aspect of teaching or materials on information technology in the field of archives education institutions in Indonesia is still very low. And if you look at the reality of the use of technology in Indonesia is very high, according to the research of Indonesian Internet Service Provider Association (APJII) 2017, said the number of internet users in Indonesia reached 143.26 million or $54.68 \%$ of the total population of Indonesia and its $74.23 \%$ baged $19-34$ years, which is the age millineal generation. From these facts, it becomes imperative for educational institutions archive field to work together with various parties who understand the technology in the learning process, so it will be a good knowledge sharing for teachers and students. Another reality states that the development of the field of archives in the realm of the Record Management private sector should be learning through field courses, public lectures, and so forth. The presence P3RI (Association of Indonesian Record Profession business) as one of the containers in the discussions related to the development of Record Management in Indonesia at least open wider horizons of knowledge.

Any field of archives of scientific development is inseparable from the role of stakeholders. Stakeholders are individuals and groups, both from within and from outside the organization, which affect or are affected by the objectives and actions in a team (West, 1998). As for the leadership of the bureaucracy, stakeholders are individuals may come from the public, community leaders, religious leaders, public officials or private organizations that affect or are affected by a policy, program, activity of public organizations in order to provide added-value to the community.

To cite this document:

Bramantya, A.R., Prasetyo, A. (2019). Between Reality and the Needs: Responsibilities of Educational Institutions in Developing Archival Science in Indonesia. Record and Library Journal. 5 (2), 136 - 149.

Open access under Creative Commons Attribution-Non Commercial-Share A like 4.0 International Licence (CC-BY-SA) (c) (i) (2) 
The influence of stakeholders who have an interest and influence over the organization's programs and educational institutions is very important. Therefore, identification of the interests and needs of stakeholders needs to be accommodated. In identifying the interests of stakeholders need to be recognized also how the position of the stakeholders of the program is being planned or executed. Do they show the attitude of support abstain or even openly reject it because it does not correspond with the interests.

Student involvement archival least given the space and facilities as possible to participate in developing the scientific field of archives. As they will be a candidate for future archivists. At present, there have been Filing Indonesian Student Association (HMKI). However, the activities carried out are still very minimal. Obstacles encountered is still very classic, which is about "budget" in order to discuss the implementation of national and international archives (Interview with the Chairman HMKI). Seeing this, of support from various archival organizers also indispensable.

New ideas and thw challenge of how archives can maintain public memory required extensive knowledge related to interdisciplinary learning, build new partnerships in collaborative research and teaching. To educate the next generation, it takes more than just teaching handbook basic practices or the assignment of writing about the filing. However, the need to immerse the students into a large interdisciplinary study and in-depth about the archives, ranging from academic culture to the general nature of science (Cox, Larsen, 2008). Eric Katelaar 1980 report on Archival Training in Indonesia explained that cultural understanding and awareness of local history, especially the younger generation is one of the important elements if it is associated with voluntary movement and orderly filing today. Other than that, to develop the scientific field of archives, educational institution which organizes graduate level education programs needed to produce an expert archivist (Katelaar, 1980). Study in South Africa regarding the development of the project involves the field of archives interpares with several universities that focus on digital archives and data. The project focuses on joint research directly to increase the percentage of graduates with doctoral qualifications, so the archival profession can be recognized by the community (Katuu, 2015). Things like this that require scientific developments in the field of archives a higher level, so that the number of courses that provide education field of archives be increased. Educational institutions that conduct educational programs bachelor level required to produce an expert archivist (Katelaar, 1980). Study in South Africa regarding the development of the project involves the field of archives interpares with several universities that focus on digital archives and data. The project focuses on joint research directly to increase the percentage of graduates with doctoral qualifications, so the archival profession can be recognized by the community (Katuu, 2015). Things like this that require scientific developments in the field of archives a higher level, so that the number of courses that provide education field of archives be increased. Educational institutions that conduct educational programs bachelor level required to produce an expert archivist (Katelaar, 1980). Study in South Africa regarding the development of the project involves the field of archives interpares with several universities that focus on digital archives and data. The project focuses on joint research directly to increase the percentage of graduates with doctoral qualifications, so the archival profession can be recognized by the community (Katuu, 2015). Things like this that require scientific developments in the field of archives a higher level, so that the number of courses that provide education field of archives be increased. Study in South Africa regarding the development of the project involves the field of archives interpares with several universities that focus on digital archives and data. The project focuses on joint research directly to increase the percentage of graduates with doctoral qualifications, so the archival profession can be recognized by the community (Katuu, 2015). Things like this that require scientific developments in the field of archives a higher level, so that the number of courses that provide education field of archives be increased. Study in South Africa regarding the development of the project involves the field of archives interpares with several universities that focus on digital archives and data. The project focuses on joint research directly to increase the percentage of graduates with doctoral qualifications, so the archival profession can be recognized by the community (Katuu, 2015).

To cite this document:

Bramantya, A.R., Prasetyo, A. (2019). Between Reality and the Needs: Responsibilities of Educational

Institutions in Developing Archival Science in Indonesia. Record and Library Journal. 5 (2), 136 - 149.

Open access under Creative Commons Attribution-Non Commercial-Share A like 4.0 International Licence 
Things like this that require scientific developments in the field of archives a higher level, so that the number of courses that provide education field of archives be increased. The project focuses on joint research directly to increase the percentage of graduates with doctoral qualifications, so the archival profession can be recognized by the community (Katuu, 2015). Things like this that require scientific developments in the field of archives a higher level, so that the number of courses that provide education field of archives be increased. The project focuses on joint research directly to increase the percentage of graduates with doctoral qualifications, so the archival profession can be recognized by the community (Katuu, 2015). Things like this that require scientific developments in the field of archives a higher level, so that the number of courses that provide education field of archives be increased.

\section{Conclusion}

Archival science more interpreted in a theoretical structure that supports the activities of archival practical, rather than academic disciplines. If the method is applied science, the science of archives will tend to be highly empirical making it a descriptive science. This tendency will make archival science seeks only to gather facts and less attention to the development of the concept as well as demanded by the development of a science through a study. Therefore, educational institutions are responsible for the scientific development in the field of archives especially Indonesia. One of the simplest ways is to establish a mind set that is systematically linked with terminology and create innovative educational strategies.

It is known that archival science is dynamic look of the concepts of ideas, strategies and methodologies that are constantly evolving, changing and adapting to the changes. Science archives also related to the nature of the archive, the structure of the creation of the archive, the organizational culture and work culture, social function and institutional functioning, the storage system of institutional records, the use of the present, the tendency of the wider society about cultural issues, legal, social, technology, and philosophy. Archivists are required to be able to adapt and have the ability to do research in order to identify and then abstracting the various changes and conceptually capable of mastering the theory, methodology and practice of archives as the impact of the changes and demands of society.

Broaden the perspective of the field of archives through archival education will give the possibility to deal with important issues in a comparative field of archives. Knowledge of archival science and discipline such that the learner was formed as a modern professional in the information age. So once again, to develop scientific archives in Indonesia, the necessary synergy between archival institutions, archival professional associations, educational institutions allied, as well as among students in educational institutions. This must be done with the agreement in the field of archives that apply universally to realize the creation of the organization of archives in Indonesia better.

\section{References}

(1989). Diplomatics: New Uses for an Old Science [Part One]. Archivaria, 28(7).

ANRI. Implementation of the National Archives Still Lacking archivist. (2017, February 7). Retrieved fromhttp://www.anri.go.id/d etail/1100-penyelenggaraan-kearsipan-nasional-masih-minimarsiparis

Asmiyanto, Taufik. (2018). Metamorphosis archivist in the Industrial Age 4.0: A Challenge in the Face of the Digital Revolution, paper presented at the National Seminar Archives Archival Management \& Future Archive in the Digital Age, October 10th, 2018, the Faculty of Social and Political Science, University of Bengkulu.

Cooperation Bureau and Public Communication, Ministry of Research, Technology and Higher Education (2018, January 17). Retrieved from https://www.ristekdikti.go.id/siaranpers/pengembangan-iptek-d an-pendidikan-tinggi-di-era-revolusi-industri-4-0/

To cite this document:

Bramantya, A.R., Prasetyo, A. (2019). Between Reality and the Needs: Responsibilities of Educational

Institutions in Developing Archival Science in Indonesia. Record and Library Journal. 5 (2), 136 - 149.

Open access under Creative Commons Attribution-Non Commercial-Share A like 4.0 International Licence 
Cox, Richard J., Larsen, Ronald L. (2008). iSchools and Archival Studies. Archival Science Journal, 8, 307. doi:https://d oi.org/10.1007/s10502-009-9092-3

Duranti, Luciana. (2007). Models of Archival Education: Four, Two, One, or a Thousand ?. Archives \& Social Studies: A Journal of Interdisciplinary Research, 1(41).

Effendhie Machmoed. (2017). Looking for Professional Development Archives In Australia: Reflections and Challenges of Archival Profession In Indonesia, paper presented at the National Seminar Archives Archival Studies Program UGM Vocational School, May 10, 2017.

Hickerson, H. Thomas. (2001). Ten Challenges for the Archival Profession. The American Archivist, 64(6).

Retieved

from

http://americanarchivist.org/doi/pdf/10.17723/aarc.64.1.0rg6525nu1437v31?code=SAME-site

Katelaar, Eric. (1980). Archival Training. Paris: UNESCO.

Katuu, Shadrack. (2015). The development of archives and records management education and training in Africa - challenges and opportunities. Archives and Manuscripts, 43(96). doi:https://doi.org/10.1080/01576895.2015.1050677

Law Number 43 Year 2009 on Archives.

Moleong, Lexy J. (2013). Qualitative Research Methodology Revised Edition. Bandung: PT Rosda paper.

Operator. (2016, January 14). Retrived from https://arsip.sv.ugm.ac.id/mata-kuliah

Penyusun. (2018/2019). Retrived from https://www.ut.ac.id/sites/all/files/images/2018/Mei/KatalogProgramStudi-Diploma-Sarjana-FE-FHISIP-FMIPA-FKIP-UT-2018-2019.pdf

Randall C., Jimerson. (2010). From the Pacific Northwest to the Global Information Society: The Changing Nature of Archival Education. Journal of Western Archive, 1(1) https://digitalcommons.usu.edu/westernarchives/vol1/iss1/2

Ray Jordan. (2018, August 16). Retrieved from https://news.detik.com/berita/d-4169005/jokowiuniversitas-di-indonesia-harus-dobrak-kebiasaan-lama

Santoso, Agus. (2016). Competence urgency Archive Media Literacy Share business. Record and Library Journal. 2(2) Doi:http://dx.doi.org/10.20473/rlj.V2-I1.2016.72-80

Scheurkogel, Hans. (2006). Master What do We Want? Wahat Master do We Need ?. Archival Science Journal, 6, 151. doi:https://doi.org/10.1007/s10502-006-9025-3

Sulistyo Basuki. (2009). Archival Terms Dictionary. Yogyakarta: Canisius.

Suprayitno. (2017). The concept of Foucault and Derrida Archives in Semiotics Perspective: Between Idealism and Reality: Proceedings of the International Seminar of Archives, 15-16 December 2017 (pp.29-52). Yogyakarta: Gadjah Mada University Archives.

Thomassen, T. (2001). Modeling and Remodeling Archival Education and Training. First European Conference for Archival Educators and Trainers. Retrieved from http://www.icasae.org/mrconfpaper1.html

Utomo, Djoko. (2017). Indonesia archivists and Human Rights, Between Hope and Reality: Proceedings of the International Seminar of Archives, 15-16 December 2017 (pp.1-28). Yogyakarta: Gadjah Mada University Archives.

Waluyo. (2018).Position, Development, and the Role of Scientific Archives in Indonesia, Paper presented at the National Seminar Archives Archival Strategic Role In Supporting Performance Public and Private Organizations, October 9th, 2018, Archival Studies Program UGM Vocational School.

West, Michael. (1998). Effective Team Work. Yogyakarta: Canisius.

Widodo Bambang P. (2017). Archivist Position in Doing Research, Studies and Development Filing System. Khazanah, 10, 75. doi:https://doi.org/10.22146/khazanah.30080

To cite this document:

Bramantya, A.R., Prasetyo, A. (2019). Between Reality and the Needs: Responsibilities of Educational

Institutions in Developing Archival Science in Indonesia. Record and Library Journal. 5 (2), 136 - 149.

Open access under Creative Commons Attribution-Non Commercial-Share A like 4.0 International Licence

(CC-BY-SA) (c) (i) (2) 
Arif Rahman Bramantya | Between Reality and the Needs: Responsibilities of Educational Institutions in Developing Archival Science in Indonesia

Zorich, Diane M. (2007). Digital Defining stewardship in the digital age. First Monday, 12(7). doi:https://doi.org/10.5210/fm.v12i7.1927 